\title{
MEASURED LEAK RATES OF THE TEMPORARY SEALS IN DWPF CANISTERED WASTE FORMS AFTER THREE YEARS OF ON SITE STORAGE (U)
}

by J. R. Harbour, et al.

Westinghouse Savannah River Company

WSRC-TR--92-171

Savannah River Site

Aiken, South Carolina 29808

DE93 002153

T. J. Miller

This paper was prepared in connection with work done under Contract No. DE-AC09-89SR18035 with the U. S. Department of Energy. By acceptance of this paper, the publisher and/or recipient acknowledges the U. S. Government's right to retain a nonexclusive, royalty-free license in and to any copyright covering this paper, along with the right to reproduce and to authorize others to reproduce all or part of the copyrighted paper. 


\section{DISCLAIMER}

This report was prepared as an account of work sponsored by an agency of the United States Government. Neither the United States Government nor any agency thereof, nor any of their employees, makes any warranty, express or implied, or assumes any legal liability or responsibility for the accuracy, completeness, or usefulness of any information, apparatus, product, or process disclosed, or represents that its use would not infringe privately owned rights. Reference herein to any specific commercial product, process, or service by trade name, trademark, manufacturer, or otherwise does not necessarily constitute or imply its endorsement, recommendation, or favoring by the United States Government or any agency thereof. The views and opinions of authors expressed herein do not necessarily state or reflect those of the United States Government or any agency thereof.

This report has been reproduced directly from the best available copy.

Available to DOE and DOE contractors from the Office of Scientific and Technical Information, P.O. Box 62, Oak Ridge, TN 37831; prices available from (615) 576-8401, FTS 626-8401.

Available to the public from the National Technical Information Service, U.S. Department of Commerce, 5285 Port Royal Rd., Springfield, VA 22161. 
KE: WORDS: Inner canister
closure, Waste Acceptance

April 6, 1992

TO: M. J. PLODINEC

FROM: $\quad$ J. R. HARBOUR and T. J. MILLER

MEASURED LEAK RATES
OF THE TEMPORARY SEALS IN DWPE CANISTERED WASTE FORMS
AFTER THREE YEARS OF ON SITE STORAGE (U)

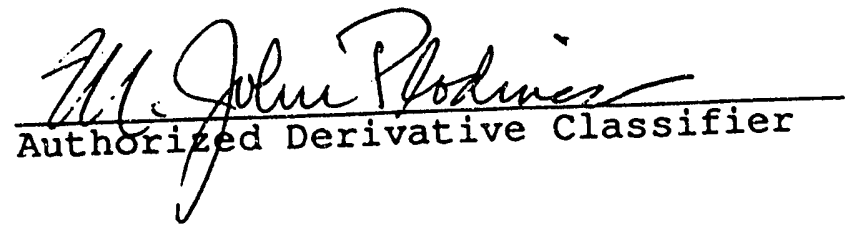




\section{INTRODUCTION AND SUMMARY}

In the summer of 1990 a study was carried out to determine the internal pressure, relative humidity, and chemical composition of the gas within the free volume of four canistered waste forms produced at TNX in May of 1988 (ref. 1). Three of these canistered waste forms were sealed only by temporary seals and subsequently stored in the TNX 'boneyard' with no protection. The fourth canister was sealed by upset resistance welding. All three canisters with temporary seals were decontaminated by aqueous frit blasting. It was important to remeasure the leak rates of these seals to erisure that leaktightness had not deteriorated during canister handling and storage prior to the time the experiments were performed. This paper details the results of two separate measurements of the leak rates of these seals.

The first set of measurements was carried out in May, 1991, three years after the canisters had been glass-filled and sealed. In this case, the leak rates were measured on the intact canisters at TNX. A second set of measurements was made in March of 1992 on the nozzles which had been removed from the canisters.

The measurements of the leak rates revealed that the the seals had actually improved in leaktightness over time. In fact, the leak rates measured three years after sealing had decreased (i.e., become more leaktight) by a factor of at least 30,000 . The second set of measurements, carried out nine months after the first set, confirmed the first set of measurements. In both cases no helium was detected by the sensors and thus, the leak rates were less than the sensitivity of the equipment $\left(\sim 10^{-10} \mathrm{~atm} \mathrm{cc} / \mathrm{sec}\right)$.

These results also demonstrate that the seals are robust, and can withstand handling and storage with no increase in leak rate.

\section{BACKGROUND}

After filling a DWPF canister with glass, a temporary seal is made by insertion of a tapered plug into the nozzle of the hot canister. The temperature of the nozzle must be at or above $185^{\circ} \mathrm{C}$ before insertion of the plug (ref. 2). As the canister cools, the nozzle and sleeve contract, and a seal is formed between the sleeve and the tapered plug. Light and Doherty (ref: 3) have shown that a measured leak rate of a seal less than $2 \times 10^{-4}$ atm cc/sec for helium gas is. sufficient to preclude the passage of water through this same seal at 5 psig for a two hour period, and 25 psig for a half 
hour period. Consequently, during operation of the DWDF, the measured leak rate of this ICC seal must be less than $2 \times 10^{-4}$ atm $\mathrm{cc} / \mathrm{sec}$ for helium before the canistered waste form can be transferred to the $C D C$ for decontamination by aqueous frit blasting.

\section{IEAK RATES OF THE TEMPORARY SEALS}

The initial leak rates for two of three canistered waste forms with temporary seals only, are given in Table I. These values were provided by Lee Goudelock and were measured in May of 1988. No record of the leak rate for canister A-7 could be found. Canister $A-7$ has the normal sleeve to tapered plug seal, while canisters $A-6$ and $A-16$ have seals made with repair plugs. Hence, for canister $A-7$, there are actually two seals present. The first seal is between the nozzle and the outer surface of the sleeve and the second seal is between the tapered plug and the inner surface of the sleeve. For $A-6$ and A-16, the nozzle was heated to cause the sleeve and tapered plug to fall into the canister. (In each case, the tapered plug and sleeve were found in the free volume space of the canisters). A new seal was then made with a repair plug. In these last two canisters the single seal is between the repair plug and the nozzle.

TABLE I

LEAK RATES OE THE TELPORARY SEALS

Canister Original leak rate (atm cc/sec)

$A-6$

$A-7$

A-16
$2.6 \times 10^{-5}$

no data

$1.3 \times 10^{-5}$
Final leak rate (atm cc/sec)

$<3.4 \times 10^{-10}$

$<3.5 \times 10^{-10}$

$<4.0 \times 10^{-10}$ 
The leak rates of these temporary seals were measured on two different occasions using different procedures. The first. measurements were carried out at TNX on the intact canisters. The small holes in the canisters generated in the summer of 1990 to do pressure, relative humidity, and chemical composition experiments, were used as ports through which evacuation of the free volume was accomplished. This was followed by backfilling of the free volume with helium to 14.7 psi. A bell jar attached to the top of the canister and connected to a mass spectrometer was used as a helium detector. The procedure entitled "Canister Plug Leak Test Procedure" (LSO No.: 901024) was followed to measure leak rates. A standard leak rate was used to calibrate the equipment. Data were recorded on the data sheets contained in this procedure. No helium could be detected for any of the seals and hence the leak rates reported are based on the sensitivity of the system for each measurement.

For the second measurement of the leak rates, the nozzles were removed from the canisters and transferred to EES. Two of the nozzles were removed using the band saw while the other nozzle was removed by arc air cutting. In this measurement, a bag was sealed around the bottom of the nozzle and then filled with helium. A bell jar was attached to the tops of the canisters and connected to the helium detector. Procedure No.: OP:L9.2-3404 was followed for the leak rate measurements and data acquisition. In this case, as in the first case, no measurable helium could be detected. The leak rates were consequently equal to the sensitivity of the system which was $<6.5 \times 10^{-10} \mathrm{~atm} \mathrm{cc} / \mathrm{sec}$. These data were collected and recorded on data sheets in March, 1992.

The leak rate of canister $A-22$ was also measured. This canister had a final seal made by upset resistance welding. The leak rate of this seal, measured by the first method, was $<3.6 \times 10^{-10} \mathrm{~atm} \mathrm{cc} / \mathrm{sec}$.

The leak rates for $A-6$ and $A-16$ measured the seal between the repair plug and the nozzle, and for $A-7$ measured both the nozzle-to-sleeve and sleeve-to-tapered plug seals.

\section{IMPACT OF RESULTS ON PREVIOUS WORK}

The initial leak rates of these seals correspond to inleakage of 0.8 liter $(A-16)$ to 1.6 liters $(A-6)$ of air over a two year period under the assumption of a 1 atmosphere differential in pressure and an invariance in the leak rates. Since the pressure differential is less than 1 atmosphere, these are maximum values of air inleakage. The free volumes of $A-6$ and $A-16$ are approximately 75 liters, which gives a 2.1 maximum percentage increase in the amount of air within the canister over two years due to inleakage. The purpose of 
the remeasurement of leak rates of these seals was to confirm that the seals had not deteriorated with time.

As presented above, the rates not only did not increase, they As presented above, the rates not with time. When one takes
in fact decreased significantly with
this into account, the amount of air inleakage becomes even less than $2.1 \%$. Since we have no intermediate measures of the leak rates, it can not be said with certainty that the the leak rates, it can not be sast before decreasing, or that
leak rates did not increase first
the additional sealing was linear with time. However, since the internal pressures of these canisters were all less than atmospheric pressure and all three temporary seals had improved, it appears that these seals were robust and improving with time. Therefore, the values measured for the improving with time.
pressure, relative humidity, and gas composition previously
on these canisters were not significantly affected by inleakage of air during the two year period since sealing.

\section{IMPACT OF RESULTS ON DWPE OPERATIONS}

If, for any reason, a glass-filled canister with an acceptable temporary seal, can not be upset resistance welded for some period of time, it will require temporary storage in the DWPF. During this time, the ICC seal must be sufficiently leaktight to avoid significant inleakage of air and water, and, conversely, leakage out of radioactive material. In the absence of self sealing, a seal with an invariant, acceptable leak rate of $1 \times 10^{-4}$ atm $\mathrm{cc} / \mathrm{sec}$ for air, will allow inleakage of 6.3 liters of air over a two year period for a 1 atmosphere differential in pressure. Since the internal pressure will be close to $0.67 \mathrm{~atm}$, the real inleakage will be a maximum of 2.1 liters. Typically, DWPF canisters will be filled to $85 \%$, which leaves approximately 110 liters of free volume. This inleakage then, corresponds to a $1.9 \%$ change in the amount of air within the canister free volume over two yisars. On the other hand, if self sealing occurred so rapidly as to be instantaneous, then inleakage over a two year period would be approximately $0.02 \mathrm{cc}$ of air. The reality is that the inleakage will be somewhere between these two extremes and will depend on the rate of self sealing. As long as the gas which has leaked in is inert (i.e., contains no foreign materials), then the WAPS (ref. 4) will be met. The results of this study indicate that che canistered waste form temporary seals are sufficiently robust and self-sealing to perform well in this type of scenario. The lower the leak rate, the easier it will be to ensure compliance (ref. 5) with the WAPS. Self sealing is clearly an added benefit here.

Further studies of the robustness of the ICC seal will be performed during the DWPF Startup Test Program. In this case 

March 19, 1992

the leak rates of the temporary seals will be measured prior to and after aqueous frit blasting.

\section{REFERENCES}

1. J. R. Harbour, T. J. Miller, and M. J. Whitaker, "The Determination of Pressure, Dewpoint, and Composition of the Gas within the Free Volume of Canistered Waste Forms (U) ,WSRC-RP-90-1167, November, 1990.

2. DWPF Process and Equipment Description, DPSOP 257-1, Rev 3. M. Light and J. E. Doherty, "Investigation of
Nondestructive Evlauation Techniques for Inspection of Nuclear Waste Canisters" Final Report, SwRI Project 7588, February 1984.

4. Waste Acceptance Preliminary Specifications for Vitrified High-Level Waste Forms, DOE/RW-xxxx, June 1991.

5. Waste Form Compliance Plan for the Defense Waste Processing Facility, WSRC-SW4-6, Rev 1A, July 1991. 
DATE

FILMED

01110193 
